\title{
Authors' Response to Peer Reviews of "Impact of Modifiable Risk Factors on the Occurrence of Cutaneous Leishmaniasis in Diyala, Iraq: Case-Control Study"
}

Asaad Mahdi Lehlewa ${ }^{1}$, MD, MSc; Hanan Abdulghafoor Khaleel ${ }^{2}$, MD, MSc, DrPH; Faris Lami ${ }^{3}$, MD, PhD; Saif Aldeen Falah Hasan ${ }^{2}$, DVM, HDip; Hasanain Asmail Malick ${ }^{1}$, MD, MSc; Razzaq Hashim Mohammed ${ }^{4}$, MD, MSc; Qais Abdulazziz Abdulmottaleb ${ }^{5}$, MD, MSc

${ }^{1}$ Public Health Directorate, Ministry of Health of Iraq, Baghdad, Iraq

${ }^{2}$ Communicable Diseases Control Center, Public Health Directorate, Ministry of Health of Iraq, Baghdad, Iraq

${ }^{3}$ Department of Community and Family Medicine, College of Medicine, University of Baghdad, Baghdad, Iraq

${ }^{4}$ Ministry of Health of Iraq, Baghdad, Iraq

${ }^{5}$ Ministry of Health of Iraq, Babylon, Iraq

\section{Corresponding Author:}

Hanan Abdulghafoor Khaleel, MD, MSc, DrPH

Communicable Diseases Control Center

Public Health Directorate

Ministry of Health of Iraq

Alandalus Square

Baghdad

Iraq

Phone: 9647901472335

Email: drhanan.cdcciq@gmail.com

\section{Related Articles:}

Preprint: https://preprints.jmir.org/preprint/28255

Peer-Review Report by Riham Al-Dubaiee (Reviewer O): https://med.jmirx.org/2021/3/e31513/

Peer-Review Report by Rihana Taher (Reviewer R): https://med.jmirx.org/2021/3/e31514/

Peer-Review Report by Abdulkareem Ali Hussein Nassar (Reviewer T): https://med.jmirx.org/2021/3/e31515/

Published Article: https://med.jmirx.org/2021/3/e28255/

(JMIRx Med 2021;2(3):e31512) doi: 10.2196/31512

\section{KEYWORDS}

cutaneous leishmaniasis; outbreak; Iraq; risk factors; risk; disease; infectious disease; disease prevention; prevention

This is the authors' response to peer reviews of "Impact of Modifiable Risk Factors on the Occurrence of Cutaneous Leishmaniasis in Diyala, Iraq: Case-Control Study."

\section{Round 1 Review}

\section{Reviewer O}

1. Thanks for raising this issue [1]. Being a control does not mean that they should not share the risk factors. A control here [2] is a person with no current lesions or history of lesions.

4. Would you please highlight the repeated paragraph, as we reviewed it more than once but did not find it.

\section{Reviewer T}

2. Because we have so many risk factors to talk about, we did not put the odds in the Abstract.

6. Because this study was part of an outbreak investigation, we did not use the traditional methods for sample size calculation. Instead, we included as many as possible of both cases and controls to have more insight into the risk factors.

8. If the reviewer can kindly point out which table he meant [3], we will correct it accordingly.

\section{References}

1. Al-Dubaiee R. Peer review of "Impact of modifiable risk factors on the occurrence of cutaneous leishmaniasis in Diyala, Iraq: case-control study". JMIRx Med 2021 Jul;2(3):e31513 [FREE Full text] [doi: 10.2196/31513] 
2. Lehlewa AM, Khaleel HA, Lami F, Hasan SAF, Malick HA, Mohammed RH, et al. Impact of modifiable risk factors on the occurrence of cutaneous leishmaniasis in Diyala, Iraq: case-control study. JMIRx Med 2021 Jul;2(3):e28255 [FREE Full text] [doi: $\underline{10.2196 / 28255}$ ]

3. Nassar, AAH. Peer review of "Impact of modifiable risk factors on the occurrence of cutaneous leishmaniasis in Diyala, Iraq: case-control study". JMIRx Med 2021 Jul;2(3):e31515 [FREE Full text] [doi: 10.2196/31515]

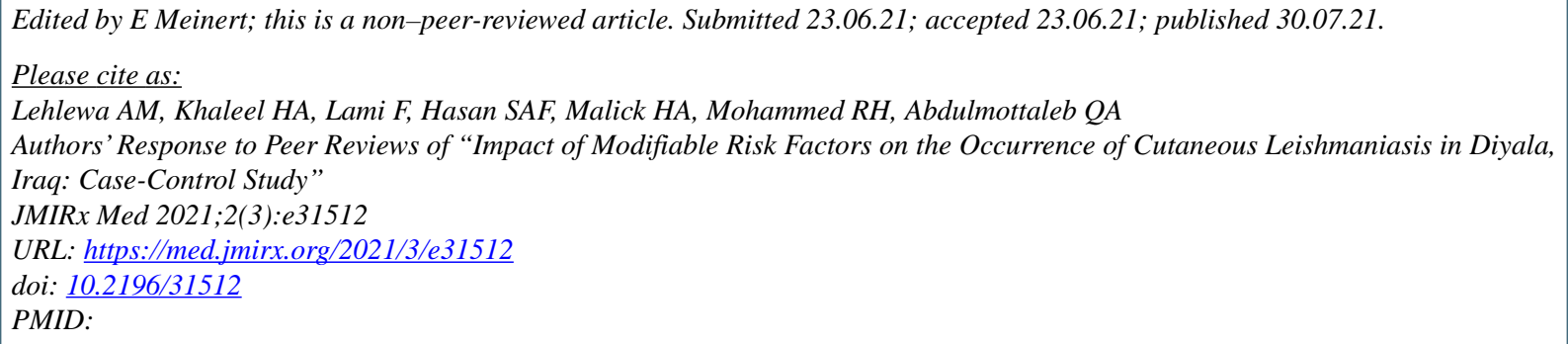

(C)Asaad Mahdi Lehlewa, Hanan Abdulghafoor Khaleel, Faris Lami, Saif Aldeen Falah Hasan, Hasanain Asmail Malick, Razzaq Hashim Mohammed, Qais Abdulazziz Abdulmottaleb. Originally published in JMIRx Med (https://med.jmirx.org), 30.07.2021. This is an open-access article distributed under the terms of the Creative Commons Attribution License (https://creativecommons.org/licenses/by/4.0/), which permits unrestricted use, distribution, and reproduction in any medium, provided the original work, first published in JMIRx Med, is properly cited. The complete bibliographic information, a link to the original publication on https://med.jmirx.org/, as well as this copyright and license information must be included. 